\title{
One Step and I am Elsewhere
}

\author{
Greg Giannis
}

\begin{abstract}
I am interested in the journeys, many of these on foot, undertaken by displaced peoples of the world, refugees, asylum seekers, migrants of all walks of life. I am currently conducting a walk that constitutes the first leg of a larger journey from the northern border with Albania to Lesvos, a journey undertaken by a group of Albanian migrants I encountered during a walking residency in Lesvos in 2008. The final leg of the journey will involve walking from the port in Mitilene, Lesvos to my parent's villages, where I encountered the Albanian families.
\end{abstract}

The work is a tribute to all displaced persons that seek to return to their birthplaces (including my now deceased parents) and this yearning to 'return' which never leaves, and their right to do so.

\section{Keywords}

migration; displacement; asylum seekers; walking 


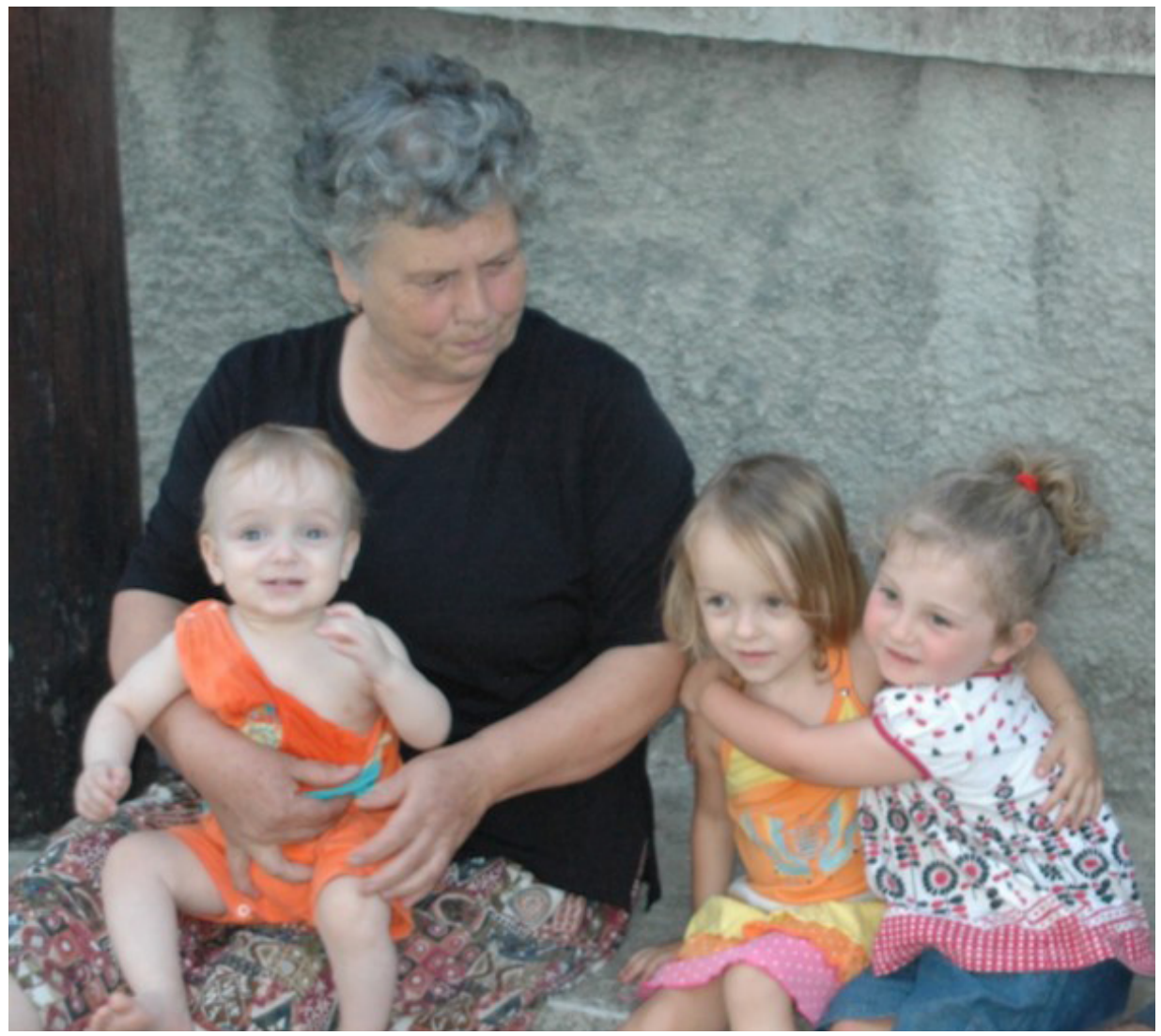

Figure 1 - Kato Tritos, 2008

"We normally think of movement as simple displacement: a change in location. What is in movement is thought of as remaining fundamentally what it was, retaining its identity across the displacement. But as the human entered into entanglements as it moved through history, it underwent changes in its very nature. It underwent qualitative change. Displacement is just the visible trail of qualitative changes in nature. Displacement is not just a shift of place. It's the index of a becoming: movement not just from one spatial location to another, but from one nature-changing entanglement to another. It's always a question of transformation - transformation in relation.” (Massumi, B. 2017, p 8)

The title of this report comes from the Theo Angelopoulos film 'The Suspended Step of the Stork', part 1 of the 'Trilogy of Borders'. One of the recurring themes of his work is immigration, the flight from homeland and the return, as well as the history of 20th century Greece. Many of his films are set in the region walked during the second phase of this project.

This project commenced in 2008 when I undertook a self-initiated residency on the island of Lesvos, my ancestral home. Both parents were born on this island and I have established a strong connection to the land through my walking practice, and some of its inhabitants through the extended family network and unanticipated encounters during the said walks. The project has from the start been a socially-engaged art project that sought to articulate and research themes of identity, migration and the displacement of peoples through performative solo and group walking, research, planned and impromptu presentations and discussions. Although considerable planning was involved in all stages of the project, much was intentionally left to chance and happenstance. 
"a/r/tography works best if we let its meandering growth determine its own directions in the becoming of publics ... [and] involves making art as experimentation, inquiring with wonder, teaching as replenishing, playfully adding the double entendre of the term "graphy" as a field of study, rather than a written text alone." (Handbook of Public Pedagogy, p302)

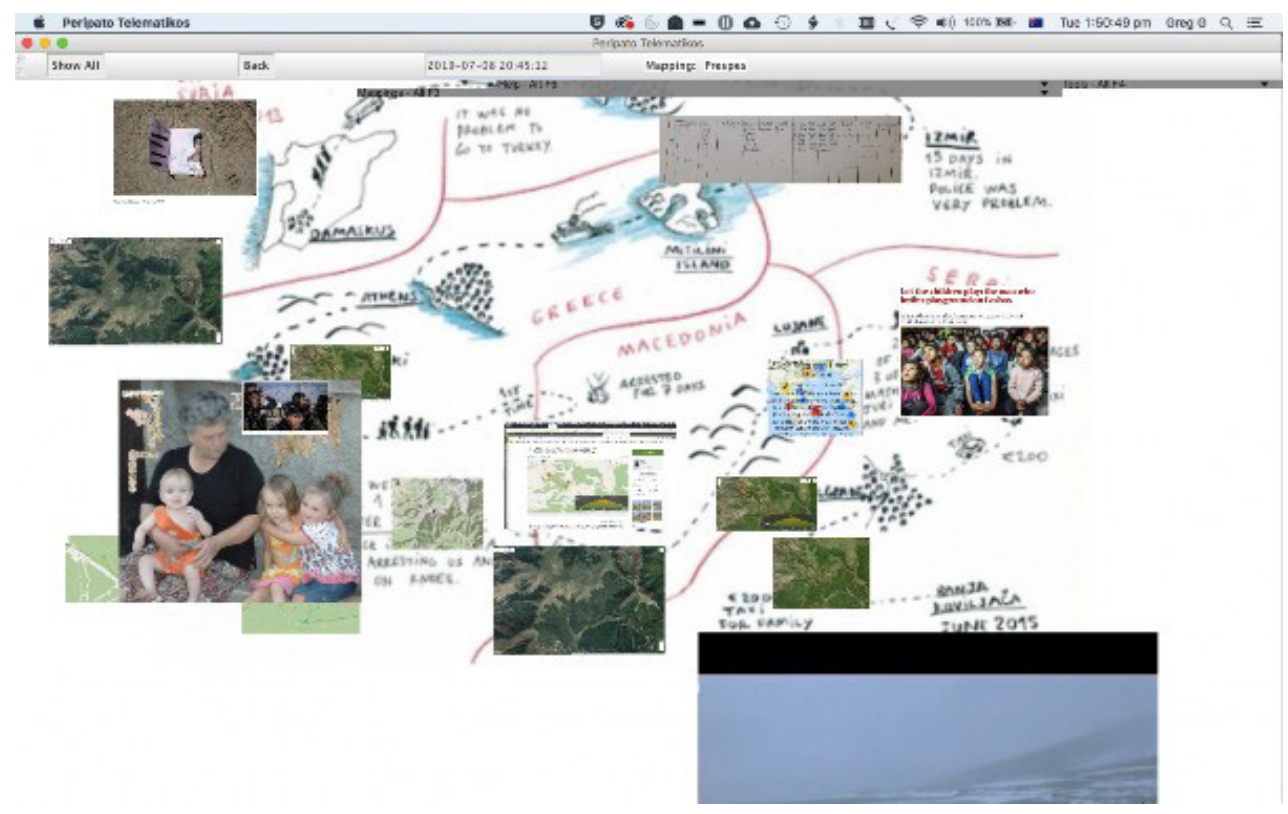

Figure 2 - Screenshot of authors mapping site: http://www.peripato.net

All of these walks have been documented using a web-based, self-developed application that captures the walks through image, sound and text and embeds these artefacts in an innovative interface that is both artwork and a critical, alternative cartography, through the content of the subjective mappings and the mechanics of the interface's functionality. The art works, essentially auto-ethnographic in methodology, are a subjective mapping produced from personal experience and from the ground up. Originally conceptualised as a space to capture walks through the media recorded during the walks and in real-time in order to engage an audience away from the site of action. Much has passed in the world of social media since this initial conception (2005), and its real-time functionality is better served by other more efficient and accessible mechanisms. Nevertheless, the platform serves a pedagogical purpose: it conveys the rhizomatic entanglements of ideas that contribute to and are a result of, the projects undertaken. Can we still conceive of the online space as one of public pedagogy? Much of this space has been hijacked and commodified by traditional educational institutions, but it has also enabled many other forms of pedagogy; consider for example, the importance of blogging.

The photo, Kato Tritos, 2008 (figure 10), was taken during this residency and documented a chance encounter during one of many walks. It informed a project that spanned more than a decade. The subjects in the photo are Ifigenia, a resident of Kato Tritos (my father's village), two Albanian refugee children being cared for by Ifigenia, and my daughter, Angelina (two and a half at the time). Ifigenia, nonchalantly explained that she was caring for the children whilst the parents worked. 
Years later (2015), at the beginning of the current refugee crisis, an 85 year-old grandmother from Lesvos was nominated for the Nobel Peace Prize.

Report: https://uk.reuters.com/article/us-nobel-peace-greece-idUKKCN0VA2V5

This was a time when many Albanian refugees had entered Greece and worked mostly illegally suffering exploitation and scapegoating. This created a great deal of tension and there were reports of violence and other injustices mostly directed at the Albanians. Despite all this, it was heartening to learn that many communities had opened abandoned houses and accommodated the refugees. The primary school in my mother's village was able to remain open as a result of the influx of Albanian children helping to revitalise some diminishing communities.

For many of the older inhabitants of Greece, the memory of their own displacement was not that distant. The catastrophic Greco-Turkish War (1919-1922) resulted in the displacement of close to a million Greeks from Asia Minor.

"Emilia Kamvisi explains how their family's refugee past urged them to help people seeking a safe haven in Greece." From: https:/www.agorathedoc.com/agora-2/category/cast/citizens/

In 2019, I had the opportunity to return to Greece and participate in the event Made of Walking (V), hosted by the Department of Fine and Applied Arts of the University of Western Macedonia, Prespes, in the north eastern region of Greece, bordering Albania and (what is now known as) Republic of North Macedonia. As a pedagogical event, it embraced staged walks in public spaces as performance, art and knowledge dissemination. Participants were led by artists, scholars and others in embodied, immersive, socially-engaged experiences that facilitated multimodal forms of expression and reception.

The region itself is replete with vestiges of the displacement of peoples. James Joyce wrote that places remember events. Many of the events at this residency addressed these traces. For example, during the Greek civil war (1946-1949), many communist sympathisers fled to neighbouring communist countries to the north over the mountains in this region; Albania, Yugoslavia and Bulgaria as loyalist forces aided by the US, UK and South Africa waged a relentless campaign of extermination. It was here, in these mountains in the north of Greece that napalm was used for one of the first times. My research also unearthed that the route I walked over the mountain had been walked by soldiers in WWI as it provided clear views of the surrounds and any impending threat. In a neighbouring town Vefi, a cemetery existed with the graves of fallen Australian soldiers from WW1.

It had been 11 years since I had last visited Greece and my personal circumstances and that of the country's had changed considerably. Both my parents had passed away and Greece's economic crisis had crippled the country. The economic crisis had had a huge impact on Greece and its capacity to cope with the unimaginable scale of refugee arrivals on its shores. The EU didn't help by shutting the borders after Europe reached the limits of its compassion, leaving Greece to cope with this massive problem alone. I returned with mixed feelings, as my own personal mourning intermingled with that of a country in destitution. The walking to be undertaken was informed by a larger concern but also for very personal reasons. The two themes sat self-consciously side-by-side. 


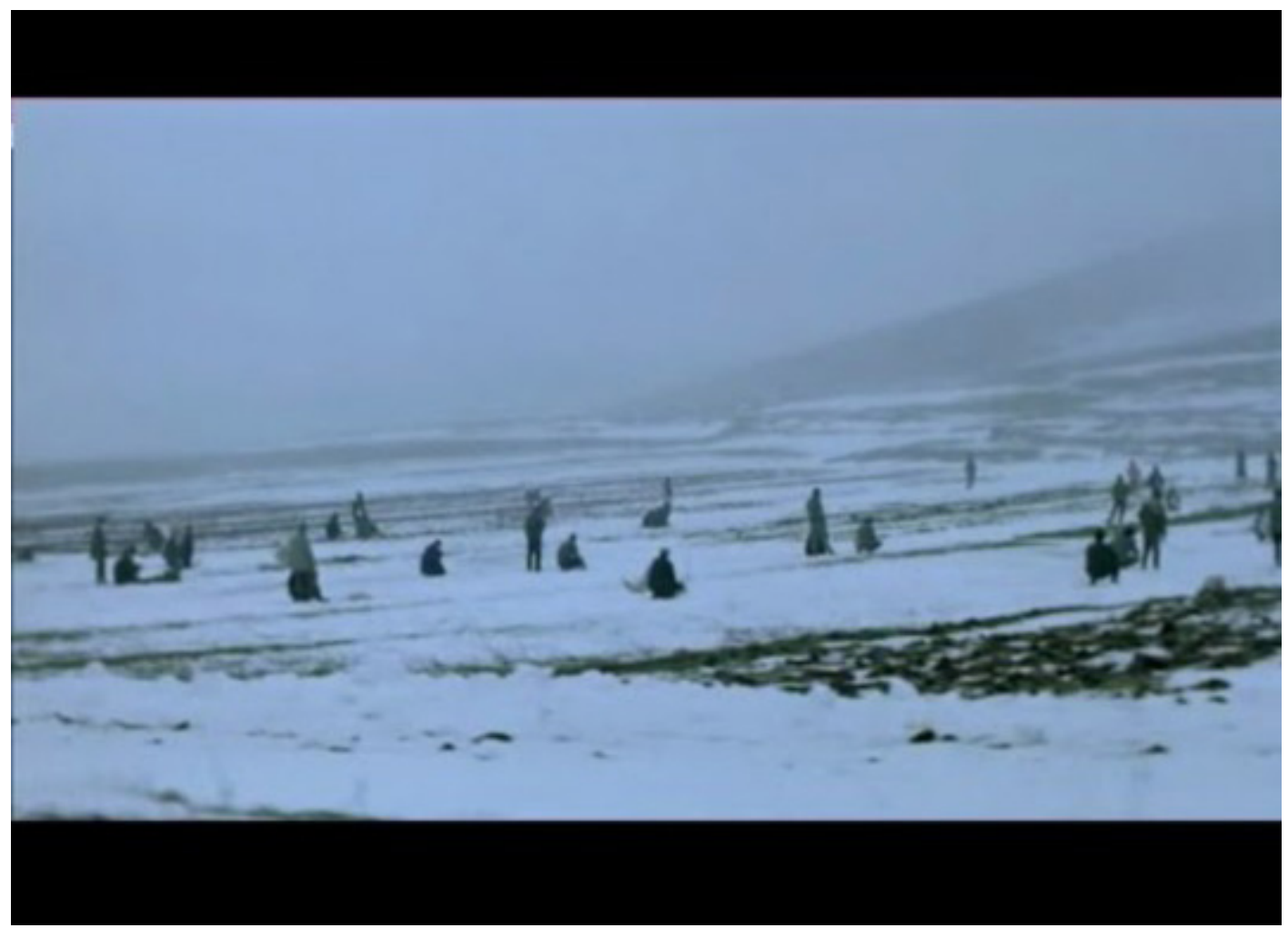

Figure 3 - Scene from the Theo Angelopoulos film, Ulysses' Gaze where Albanians can be seen crossing the border during a snow storm.

I wondered what had happened to the Albanian family I had encountered in 2008. The Made of Walking event was taking place close to the Albanian border. Many Albanian families crossed into Greece in this region. I wanted to somehow retrace this family's journey; from the frontiers to their home in Lesbos. To pay tribute to and honor them and for that matter all refugees and other peoples that have been displaced and yearn to return to their lands; as had my own parents and their brothers and sisters.

And so, the research began. My proposition was to cover the route from the border to Lesbos. How much of this could I walk? The border region to Thessaloniki was some $200 \mathrm{~km}$ and there were constraints I had to work within. I had never been to this region so knew nothing of the terrain and would not have time to do any reconnaissance. I poured over maps of the region, trying to ascertain as best I could the amount of walking that could be achieved realistically in a day.

I made extensive use of openstreetmaps (http://www.openstreetmap.org) as it provided far richer information than the default Google Maps and at no expense to my privacy and to counter hegemonic and monopolistic practices that play into and reinforce existing power structures. Cartography has a long history with colonialism, and this continues to the present day. A simple example is Google maps omission of Palestine. (The removal of Palestine by Google Maps https://www.thebigsmoke.com.au/2018/11/29/removal-palestine-googlemaps/). This simple strategy, provoked and informed others that engaged with the project to consider the embedded subjectivity and politicisation of the practices of Google and other dominating technology corporations. 
I contacted organisations in the region and the hosts of the event for information. My biggest concern was the route over the mountain. It seemed that there was a clearly marked national trail, E6, so this gave me some reassurance. I was traveling alone so needed to take care. The weeks before the event, a letter was sent to all participants advising of the "dangers" of walking alone in the region; bears, wolves and wild dogs inhabited the mountains. I needed to break up the walks into manageable chunks and organise accommodation along the way. I settled on walking from the border to the city of Florina, the region's major hub, some $65 \mathrm{~km}$. The walking was to be conducted over a number of days, not all consecutive nor in the same order. Some legs, I walked alone and others with participants from the residency as scheduled events. The latter I led after having consulted with locals to ensure the safety of participants. This was the middle of summer in Greece and temperatures created very challenging conditions.

I boarded the train from Athens to Thessaloniki, shortly after arriving. This train journey had, in the early days of the refugee crisis, been termed the "asylum express" as thousands of refugees had used it to get to the north of Greece.

"The overnight train from Athens to Thessaloniki might as well be called the Asylum Express." (https://www.thenation.com/article/this-is-what-greeces-refugee-crisis-really- lookslike/ 16/6/2019)

I changed at the small town Plati for the final leg of the train journey to Florina. On this very pleasant 8-hour train journey, I sat with a young artist who was on her way to volunteer at the Made of Walking event and an elderly gentleman, Panagiotis, who conveyed his own story of displacement. This was the first of many such stories. My experience has been that there is a strong desire to share these stories and many of this generation do so with little prompting. This impromptu exchange was one of many experienced throughout this project.

"[A]rt's public pedagogical work must always remain indirect, allowing unimagined and multitudinous responses and movement" (Handbook of Public Pedagogy, p311)

Panagiotis' situation was not unlike that of many in the north of Greece; migrating for economic reasons, an extended stay in Germany, raising families and integrating, but eventually returning. Many yearned to return to their ancestral homes, never fully settling in the new countries. I had witnessed this in my own family. My father and many of his generation never lost the desire to return to their homeland. I also witnessed mental health issues amongst that generation of migrants in my immediate and extended family. I have

come to understand that for many, the separation was too traumatic, and these migrants were not forced to leave in the same way that current refugees are. One cannot begin to compare the trauma and lives that the current refugees have faced and how their lives will pan out. These art events have the potential to inform publics of the trauma and consequence experienced by displaced peoples, to help us better understand and empathise.

"[A]n arts-based public pedagogy that engaged with performative, aesthetic modes of pedagogy, unconcerned with a particular learning outcome or goal, but seeking to raise political and cultural questions through public interaction and togetherness." (Powell, 2019) 
Upon arrival in Florina, I felt I had arrived at a place far removed from any of my previous experiences in Greece. A place with abundant light and the clarity afforded by the neighbouring mountains. The air was delightfully clear and fresh, the privileges of a town with little automotive traffic and a small population.

\section{Florina to Pisoderi}

In the morning, I organised to have my baggage sent ahead of me and left the town with a small day pack containing a few essentials. Despite all the research, what lay ahead was mostly a mystery. This day's walk, approximately $20 \mathrm{kms}$, was to take me to a small village called Pisoderi, ascending some 800 metres, where I would spend the night and then begin the mountain crossing on the following day.

I left Florina both exhilarated and with some trepidation at the thought of what could be. After many months of research and organisation I was now here. Through this immersion, I was "presencing", being fully present both mentally and physically.

I tried to stay close to the river Sakoulevas, leading out of Florina as much as I could without having to cross into private property. My route was due west and the chances of getting lost were minimal, so I seldom needed to consult a map. I took in the surrounds with relish, feeling a type of return, despite never having been here before. The scents, sounds, flora and fauna creating a heady, intoxicating mix. My senses satiated; thoughts of the previous night's conversation with Yannis the curator of this residency and my recently departed mother. The wild greens underfoot reminiscent of the "horta" my mother loved, and a strong scent of jasmine in the air. There were moments when I became aware of my body moving effortlessly, rhythmically without interruption, machine-like, unaware of the resistance offered by the land. I was walking uphill, and I could feel the temperature drop ever so slightly. Behind me the town of Florina, spread across the valley.

I reached the small village of Alona, much to the apparent surprise of the few locals I encountered. Children scampered in the village square and I sat at one of the two coffee shops. I wasn't sure whether they were open, but they seemed happy to find me a lemonade which I enjoyed with great relish.

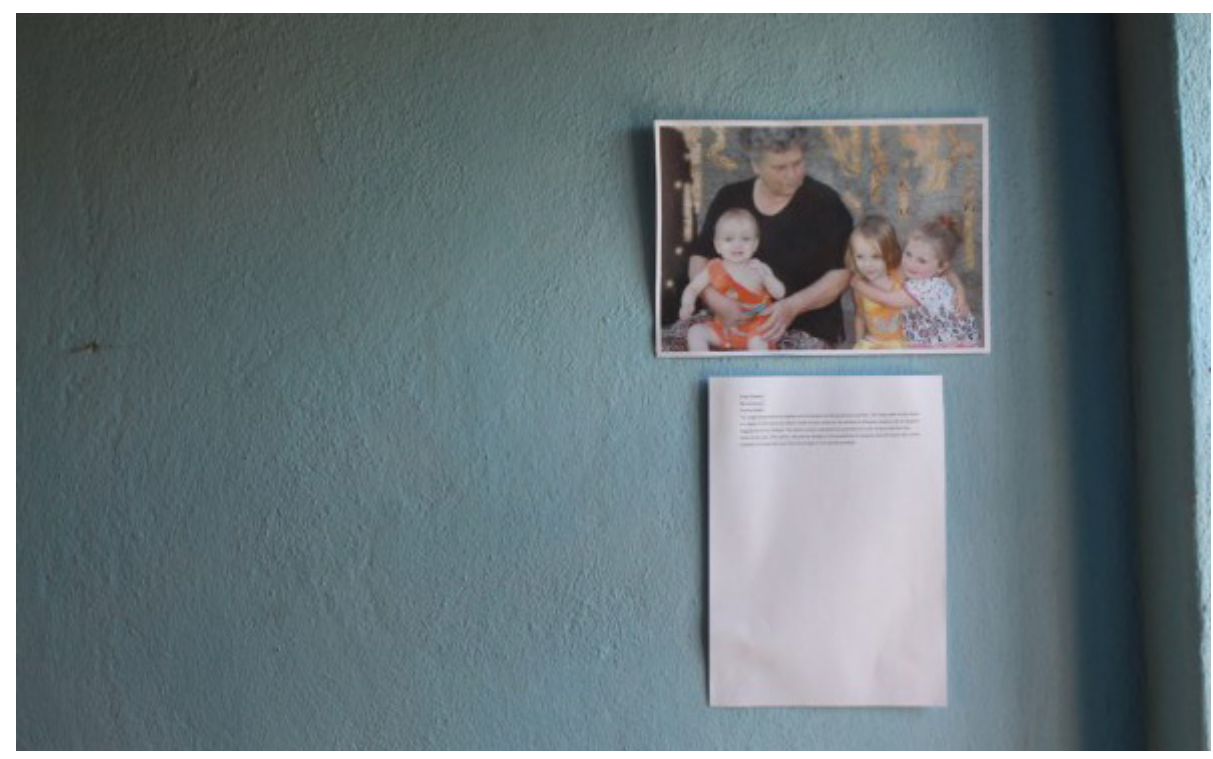

Figure 4 - Displacements, Giannis 2019. 
'Walking Practices/Walking Art/Walking Bodies", an exhibition of Walking Encounters and Conference at the Byzantine Museum of Agios Germanos. Greece, July 1-7 2019. Department of Fine and Applied Arts of the University of Western Macedonia. The work, Displacements, exhibited at the Byzantine Museum of Agios Germanos, is based on the photo taken in 2008.

\section{Pisoderi to Agios Germanos - over the mountain}

This walk took me over magnificent mountains with panoramic views across the three nations, carpeted with a kaleidoscope of wildflowers and equally spectacular butterflies. The conditions on the mountain, the heat, and my state of mind often blurred the two.

I started the climb at $8 \mathrm{am}$, closely pursued by a white dog which was initially unsettling given I was heading into the mountains on my own. I had the conversations from the night before ringing in my head and as a I walked through the forest, I felt somewhat uneasy about what could be lurking hidden behind the trees. I was told many stories about the antics of the brown bears and that if I confronted one to walk in the opposite direction. Mind you there were no stories of bears attacking people. I realised that I was walking at quite a pace and combined with the uphill grade my heart was racing. The dog I mentioned earlier seemed to be accompanying me and posed no threat from what I could make out. He just scared the bejesus out of me as he burst from the forest either side of the track at regular intervals. Once clear of the forest, I calmed, and my pace was regular. I no longer felt alarmed as I could see clearly all around.

I could see the wind turbines up ahead. This was my first waypoint.

I arrived at the first peak in what seemed little time. This gave me confidence as I felt I could cover the distance with plenty of time to spare before sundown. It was very windy and cold at the peak, fortunate to have brought my jacket amongst the few things I carried with me. I spotted a little brown bear lying on a metal box at the base of one of the turbines, warming itself in the sun. It followed me intensely with its gaze. I kept walking.

Beyond the first peak, I followed the ridge of wind turbines. At a particular point I needed to veer westward, as the ridge with the turbines continued north. I was still following a dirt track, so the walk was relatively easy compared to what I was about to encounter. I had set myself a fairly steady pace and seemed to be making good progress. I noticed an abandoned grey brick building up ahead to my left and did not think much of it as I rambled past at a heady pace. The road started to descend into a forested area and things did not seem quite right. I paused to check my location on the map and came to the conclusion that I had missed the turnoff for the E6 track. I had overshot the turnoff by about $2 \mathrm{~km}$ so walking back cost me roughly an hour. In retrospect, this would have been a considerably easier, albeit longer walk, if I had followed the road, but the E6 national hiking track was more direct and what I had intended to walk. I doubled back.

I realised that the grey building I had spotted earlier was the little red house symbol on the map that I had made enquiries about before I left, from Australia. The map indicated that I could access the walking track via this building, so I climbed a dirt track leading to the building but had no luck locating the track. I returned to the main dirt road and continued searching. I could not locate the beginning of the E6 track. There was no signage or visible goat track. I checked a description of this route I had found on an app called Wikiloc from 
previous walkers from 2017. It indicated that the track began adjacent to a small roadside altar as seen all over Greece. There was a broken, rusted old pole and a hint of a goat track. I figured this had to be the said track but obviously poorly maintained as I was able to confirm days later. I proceeded to follow what seemed to be the track but any trace very quickly disappeared.

I quickly found myself walking through knee-deep thick undergrowth that slowed me considerably. I was not happy with this rate so began looking at options. I could clearly see the saddle that I needed to get to but no apparent path or track. To my left, a small forest covered the valley and I could see that the edge followed a contour line in the direction I wished to go but well below the saddle I wanted to get to. I descended into the valley, thinking that forest edge would be a possibility but once there realised I had to climb significantly to get to the saddle, another mistake. The climb back up to the saddle was exhausting, steeper than I had estimated. I needed to stop every 5-10min to catch my breath. With no track I was walking through thick ground covering, often knee deep with lots of thistle, repeatedly scratching my calves. I became numb to the pain of the scratches. I soldiered on with some trepidation given that I couldn't see what I was stepping into.

Stepping into the unknown felt liberating but also compromising as I was here on my own, hours from the nearest village. Wherever possible, I took advantage of rocky outcrops to break up the walk and for short rests, tapping every rock I stepped on to scare away any snakes. Fortunately, I did not encounter any during the whole walk. I was also seriously concerned to not injure my ankles. I had a significant way to go and walking at an angle to the grade, with uphill to my right, my left ankle kept rolling. To this day, the memory of my rolling ankle returns whenever walking a similar grade.

In other walks that I had staged with participants in previous years, I had contemplated the affect of walking with some sense of precarity and how this would impact the memory of the walk. With senses naturally heightened, our minds reaction to potential danger, would an experience be better remembered? Would this impact the learning gained from an experience or would it detract?

Finally, I made it to the saddle, hot but relieved and with next peak ahead of me. The official path climbed over the peak, along the next ridge, and then up to the final peak, beyond which there was no more uphill walking. I could see that it was possible to follow a contour line and skirt the two peaks to reach the destination beyond the highest point. I decided that I didn't need to walk over the peak to reach my destination which would save me considerable effort. I had given up on strictly following the E6, it was not cleared anyway, and many routes now offered themselves, all equal in terms of track condition with some less steep.

As I followed the contour line, I began to notice cow pats. Farmers had taken their cows along the route I had chosen! It made perfect sense. Why would a farmer take a steep route when following a contour line would be far less strenuous and dangerous for this cumbersome beast, one not made for such terrain; top heavy and prone to toppling sideways. The challenge was then to follow the contour where it was the least steep, climbing occasionally when safe, in order to traverse this terrain. I began to feel the terrace or ledge created by the cows beneath my feet. I had become bovine and was making good progress. That or I had become delirious under the intense heat of the midday sun. 


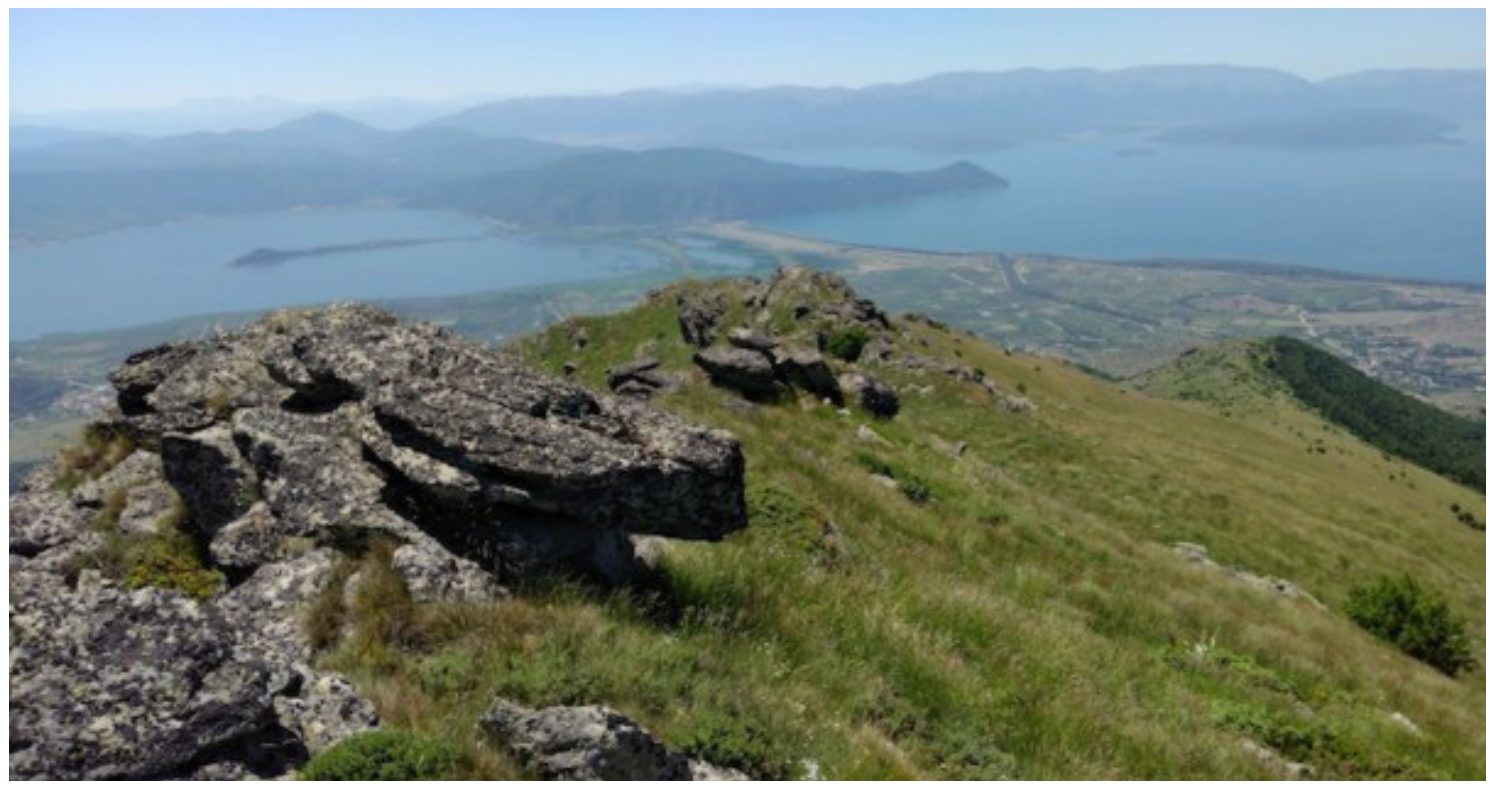

Figure 5 - The Balconies overlooking 3 countries

I continued in this fashion until I finally reached the ridge beyond the two peaks. I could now see to the north and was somewhat elated. I finally stopped for a drink and a quick bite. My canine friend was still around somewhere. He too was battling with the conditions. Up ahead I could see what was referred to as the 'balconies', a rocky ridge one side of the peak Posistra. From the balconies, the view across to Albania and North Macedonia revealed itself as did many of the villages in the valley below.

Goat-like, I leaped across the rocks, enjoying their solid and uncluttered surface. I slipped and gashed my left-hand. I didn't care. I was so overjoyed to be able to see my destination. I bound the wound with a sock. I hadn't bought much else with me which was an oversight. I wondered if I was visible from the valleys below. Had anyone seen me slip? Days later I surveyed the peaks from the valleys below to help identify where I had been.

Descending into Agios Germanos, my destination, I hoped to be able to follow the E6 track. But again, there was no visible track so I struggled through more thick undergrowth for some time. To my right the terrain dropped into the river valley and a forest. This river led to Agios Germanos. Could it be an option?

I risked it and dropped into the valley and forest. Where were those wild dogs? The terrain became very steep and I slid on many occasions further down towards the river. A dense cover of leaves covered the steep banks. The river itself still seemed very far off and I started worrying I had made a mistake, but I knew I could not climb out. It was too steep.

And then a walking track. Bliss!

The path was covered with leaves a metre thick. Like walking on snow. And cool under the canopy of the forest, pierced by mottled sunlight. I had entered a dream.

I reached the village at 5pm, 9 hours after leaving Pisoderi. I sat at the first café I encountered and ordered a beer. Outside the café, but as close to me as possible sat the white dog. 


\section{The border to Psarades by boat}

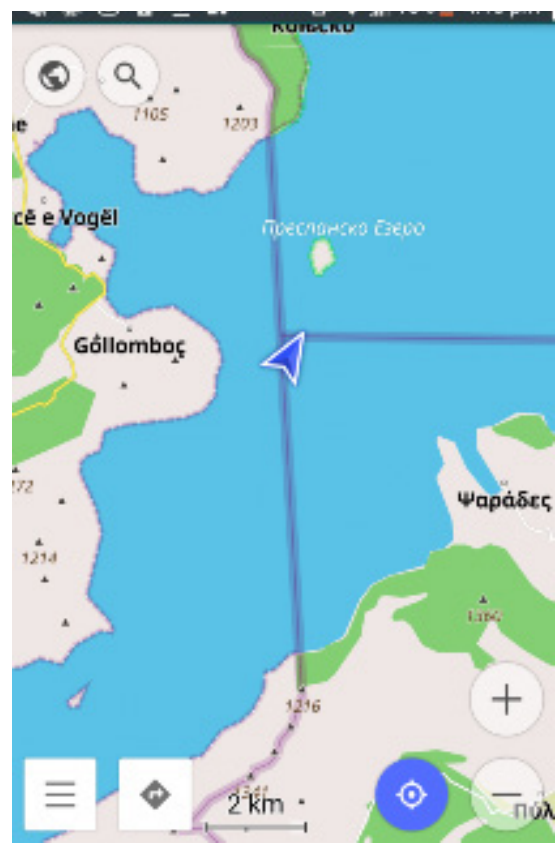

Figure 6 - Screen capture from OSM app (openstreetmaps) on author's smart phone.

The border or borders engaged many of the participants at this event. One experienced walker crossed illegally from Albania, covering some $200 \mathrm{kms}$. A Brazilian artist flew to Albanian and then commuted to Prespes. An Italian collective, known for its walking practices, Stalker, teased the border officials at the nearest crossing point by guiding a group walk to the crossing. The situation in this region had very recently changed. Old rivalries had created a border region that could not be legally crossed at many of the available and nearby points. The Prespes Agreement ratified some weeks before the gathering ensured that these decadesclosed border crossings would once again open. One scheduled event took a group by boats to the location of the meeting of the three borders in the middle of the lake, Greater Prespes. Armed with our GPS-enabled devices, we were all able to track our location as the boats approached this intersection of national boundaries. Once near as practicable to the junction we were permitted to swim into the neighbouring countries, crossing the borders with no formalities or impeding danger other than the threat of the coast guard from the neighbouring country taking umbrage at our indiscretions. An activity, both exhilarating and unsettlingly obscene. It was truly a moment where our privilege became apparent. Whilst we enjoyed swimming across borders for its novelty, at the eastern frontiers of Greece, thousands risked life and limb crossing a $10 \mathrm{~km}$ stretch of water to escape the misery and destruction facilitated directly or otherwise by our countries.

"Walking typifies the dual experience of colonialism: the lone white subject of Western Modernity surveying His landscape as possession and diasporic subjects walking their displacement and dispossession." Dr Kathryn Yusoff. (Springgay and Truman, 2018 p12)

From the borders of Albania, Macedonia \& Greece, using a combination of boats, walking, trains, aeroplanes and walking again, I arrived in the village of Kato Tritos, tracing the route that this and many other Albanian families travelled, approximately 11 years since my last visit and encounter with the Albanian children in the photograph. 


\section{Lesbos}

The multifaceted project involved many discussions about the displacement of people, testimonies, an exhibition, the creation of a new online work [Prespes at http://peripato.net], an artist residency (kindly supported by ASEF \& the Department of Fine and Applied Arts of the University of Western Macedonia), leading groups for walks into the mountains of Prespes, solo walks, participation in the web-based performance "Reading of the Nauru Files", working with the NGO "Home for All" helping refugees on Lesbos \& tracing of personal stories of migration through the interrogation of public records.

I was now in Lesbos, for the second leg of this project. I had last been here in 2008 for 3 months. That residency involved many walks around my parent's villages: Filia and Kato Tritos.

\section{Volunteering with the NGO Home for All.}

Before leaving Australia, I had also researched how and where to volunteer on the island of Lesbos, the site of one of the major refugee camps in Greece. I discovered an extensive network of NGO's from around the world providing a variety of services, mostly on a voluntary basis.

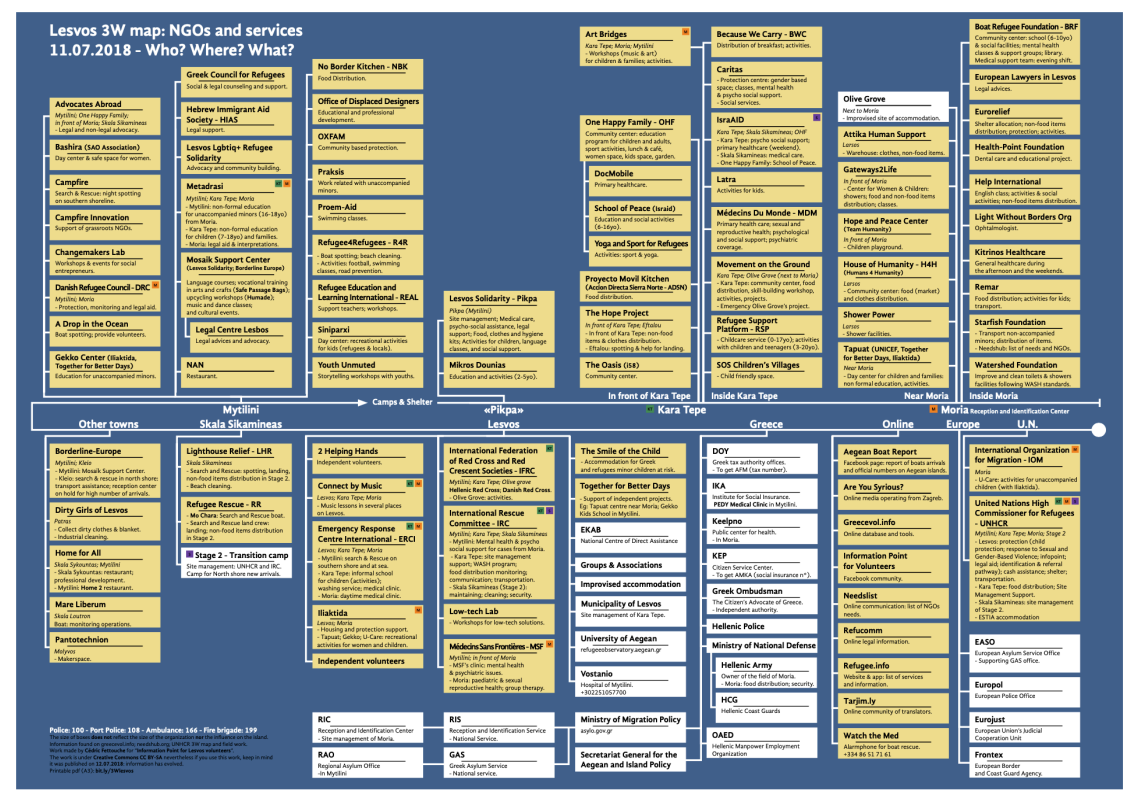

Figure 7 - https://www.opoiesis.com/ressources/3w-map-of-ngos-and-services-in-lesvos/

I also discovered some fellow walking artists that had engaged with the refugee community and hoped to be able to collaborate with them. Hilary Ramsden, academic, performer and clown conducted a chip walk with the refugees, walking from the main camp at Moria to the NGO "Home for All" approximately $11 \mathrm{~km}$. This is documented here in this video, "Women Volunteers on Lesvos" produced by Kelly Chan, a student and academic I encountered at an unrelated meeting in a university in Melbourne a few months before the trip. There were many moments of fortuitous serendipity throughout this project. It was quite difficult to find an NGO to work with as we had limited time, and many required a minimum stay. I have relatives there and have spent time there over a span of 30 years.

Furthermore, my spoken Greek is proficient. Nevertheless, many organisations could not accommodate volunteers on a short-term basis. In one of many exchanges, I discovered, Home for All, an NGO a few kilometres from my father's village, the location of our residence on 
the island. Home for All was run by a couple, Nikos and Katerina, that lived in my father's village and had intimate knowledge of my family, having associated with my parents and paternal grandparents. They were more than happy for us to volunteer with their organisation. This proved to be a truly wonderful engagement and experience, an unforgettable one that will resonate for my whole family for years to come. A formative experience of demonstrable humanity and charity.

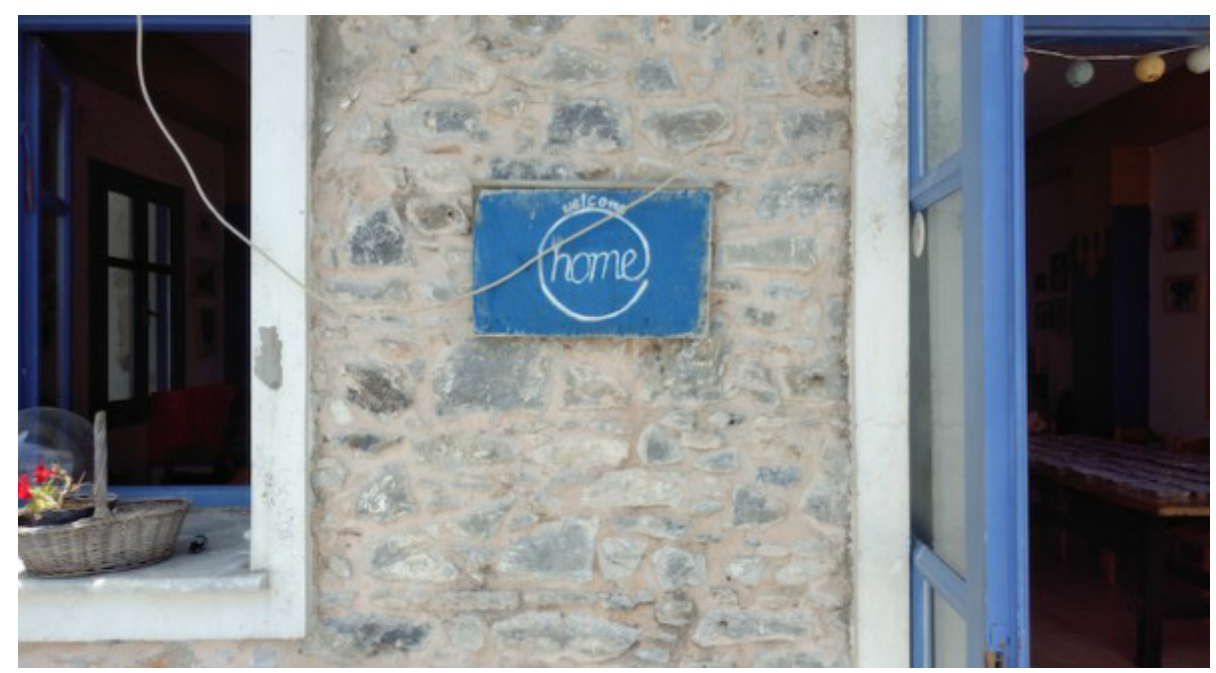

Figure 8 - Home For All 2019

The work involved preparing, delivering and distributing meals to the infirm at the camp, specifically for those that could not stand in a queue for 3-4 hours or had special dietary requirements. They also shuttled small groups of adults, women and unaccompanied minors to the restaurant Home for All. At the restaurant volunteers would prepare and serve fresh meals and provide some activities such as games and crafting for the children, swimming lessons, music and more.

Delivering the meals involved entering the camp and locating the recipients' accommodation, often having to enter their private spaces to locate the correct recipient. It was not unusual to be invited into the homes for tea and snacks.

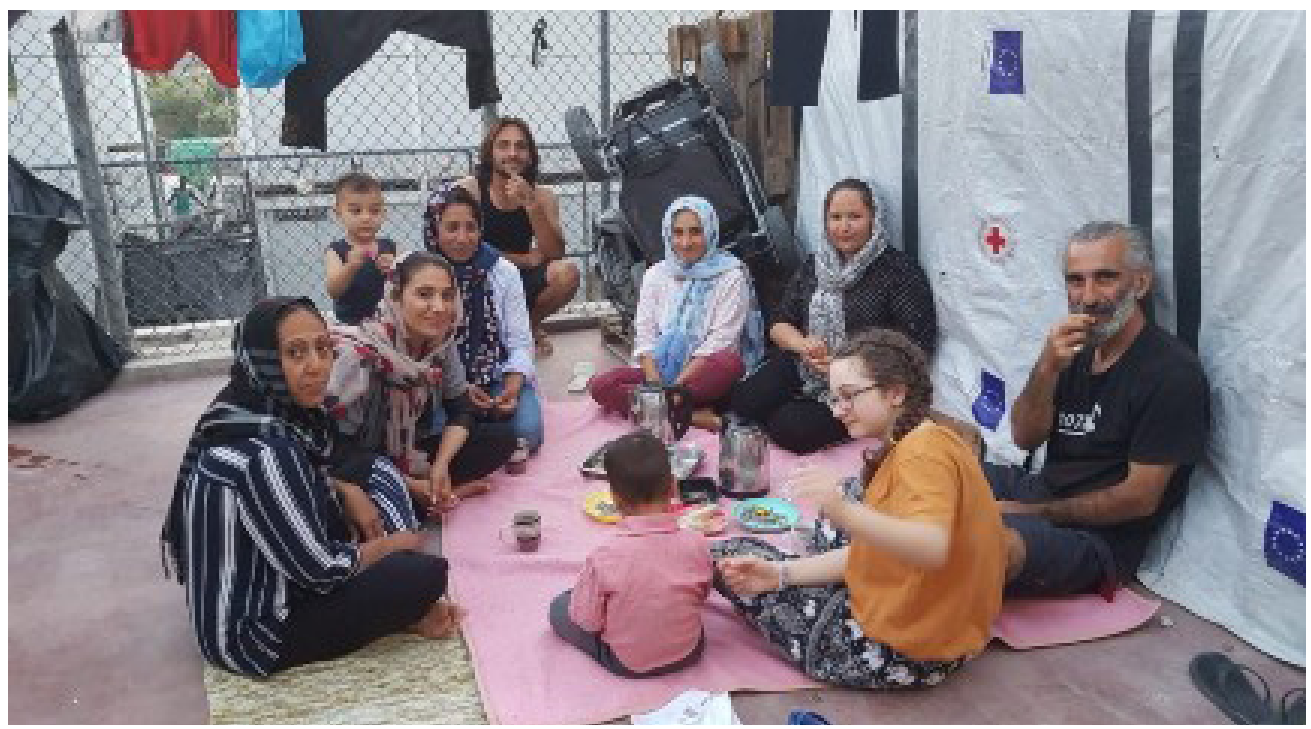

Figure 9 - Tea with Afghani family at Moria Refugee Camp, Lesbos, Greece 2019 


\section{Online Collective Performance Reading the Nauru Files}

Over a period of 24 hours volunteers from around the world performed an online reading of the Nauru Files. I read my section from the Home For All NGO base. Many observers noted the setting added urgency and context to the reading.

"The Nauru files are the largest set of leaked documents published from inside Australia's immigration detention system. They are a set of more than 2,000 incident reports from the Nauru detention centre, written by guards, caseworkers and teachers on the remote Pacific island. They set out every reportable "incident" on the island. Such events include attempts at self-harm, sexual assaults, child abuse, hunger strikes, assaults and injuries."

$<$ https://www.theguardian.com/news/2016/aug/10/explainer-how-to-read-and-interpret-thenauru-files last accessed 27/09/2020>

\section{Ifigenia and the Albanian Family}

In the village of Kato Tritos, searching for my grandfather's house, by chance, I recognised Ifigenia in the street (the subject of my photo inspiration for this journey). Whilst introducing myself and in a moment of true serendipity, the Albanian boy walked by. They are photographed here, with my daughter, Kato Tritos, 2019. The girl being hugged in the original photo and absent from this one, we are told is well and the family truly settled in Greece.

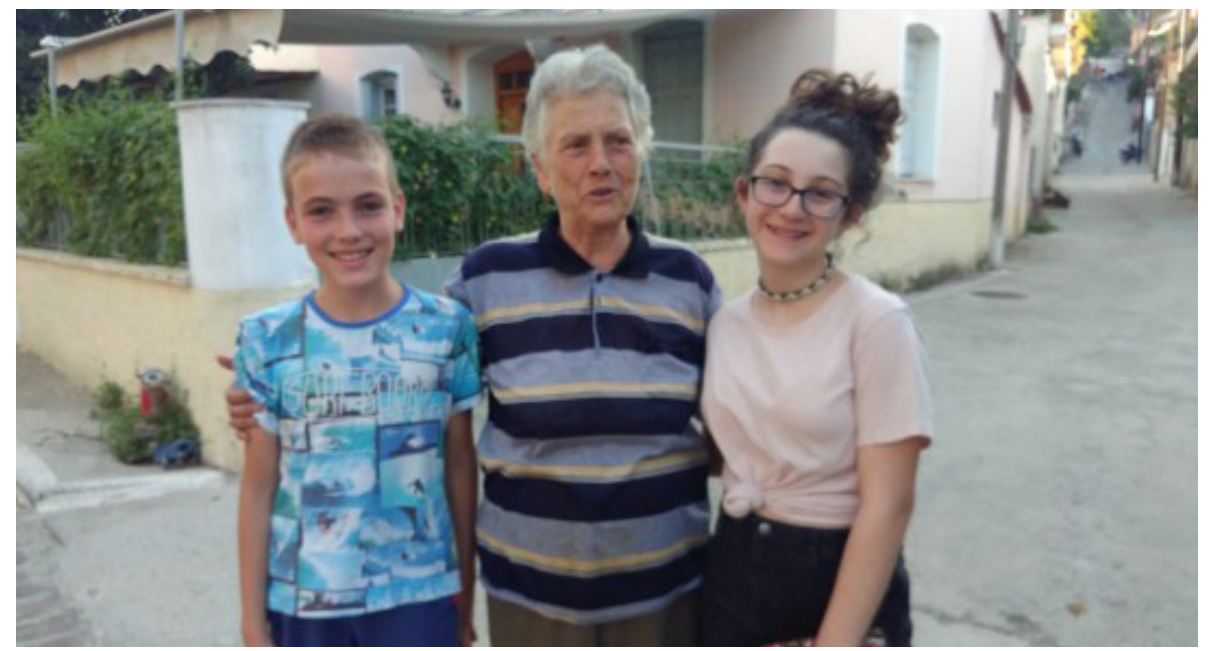

Figure 10 - Kato Tritos, 2019

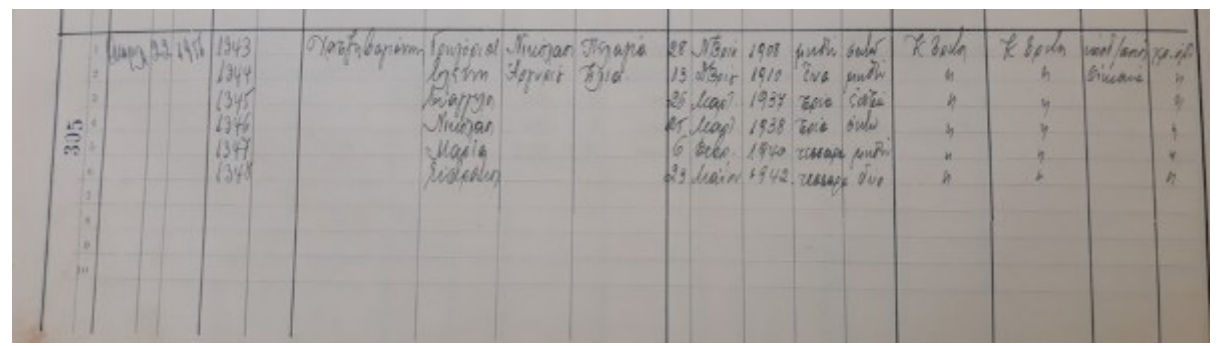

Figure 11 - family records from municipal archives recording the birthdates and place of my paternal grandparents.

The project continues. The small shack on Lesbos, that my family has inherited will be utilised and maintained by Nikos \& Katerina from "Home for All" to use as they see fit, for example to house volunteers from all parts of the world while the crisis continues. 
My family will always have ownership and exclusive access but during the many years that it usually remains empty it will be put to good use. This small but sentimentally important space will become a hub for further related works, and this gift is a tribute to the humanity shown by my parents and grandfather.

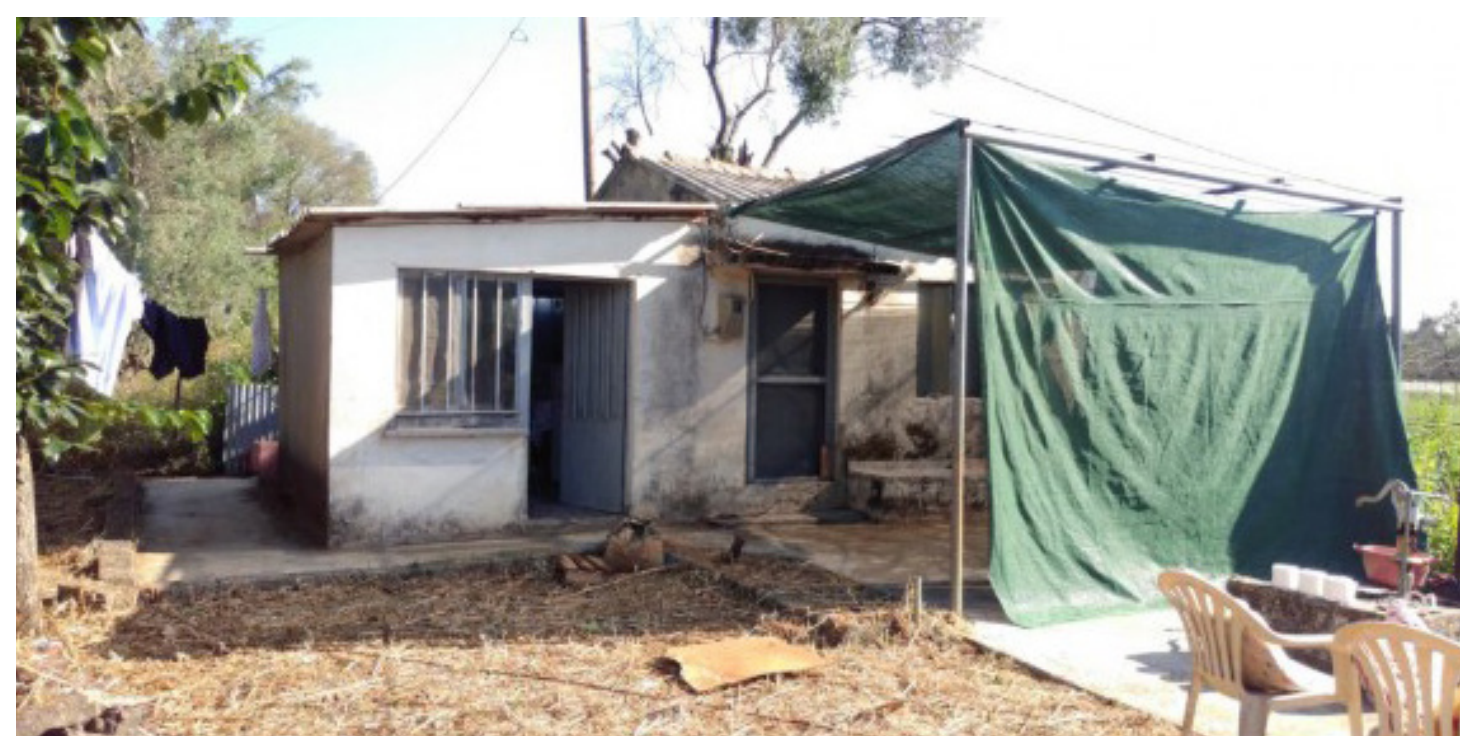

Figure 12 - the shack at Pigadakia 2019

It itself has become an integral part of the project narrative, housing and bearing witness to many generations of displaced people. It was originally used by my grandparents, whom lived with the Turkish occupiers and spoke Turkish before the forced eviction and massive displacement of 1922 .

Shortly after WWII, the Greek civil war erupted. This caused another massive displacement as many Greek communist sympathisers fled to the northern communist countries. My grandfather was sentenced to death but was subsequently pardoned and ended up serving 3 years in jail. Despite this setback, my grandfather went on to become a much-respected member of the community as he helped many. For example, he made shoes for the villagers during the destitute years that followed WWII and the Greek civil war. He was responsible for changing laws that allowed residences to be built in the region known as Pigadakia (Little Wells). Therefore, he would have built and firstly occupied the space. My parents lived there during their attempted return to their birthplace. It was not successful for many reasons and mum referred to this period as her second exile. My uncle and auntie, permanent residents in Australia, have used it often as have I, a 2nd generation Greek-Australian and now, my daughter too.

More recently, Nikos from "Home for All" helped an Iraq refugee family survive the winter of 2109/2020 and provided them with free housing in the little shack. The family has since left and relocated to Crete.

The generation of my parents regularly returns to their homelands as the draw and yearning of 'home' and the land never leaves them. It is through my own engagement with the land and observing the tireless yearning of a generation of immigrants, that I have come to have a greater appreciation for the importance of country to all those that are displaced, and furthermore, the importance of the ability and right to return. 


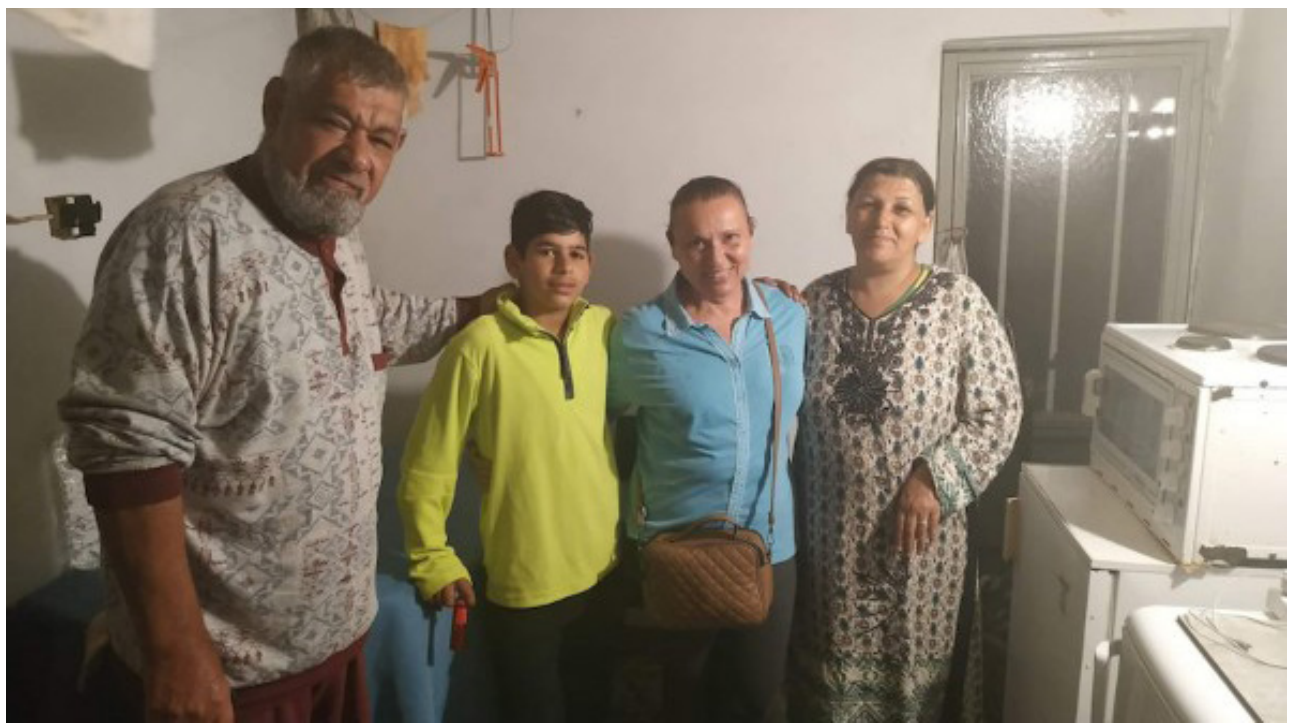

Figure 13 - Katerina (2nd from right) and Iraqi family at Pigadakia shack (2019)

During this visit, I initiated the process to transfer of ownership of this land, claiming my inheritance. Unfortunately, allocated time to do this has expired but a lawyer assures me that it can be resolved. Either way it will be a lengthy and complicated process, a process that for many is so cumbersome and costly that it is easier to relinquish any claims.

\section{Conclusion - Final Words}

This multi-faceted project merges art, performance, cartography, autoethnographic research, community engagement, public and private histories and has its roots in an ongoing project of identity and migration. Its relevance transforms with time and the events of the current milieu. Where this project will go from here (as it will continue) is difficult to ascertain given the current crisis, a global pandemic. The shack on Lesbos remains idle, but a lure for what may come next. I have asked the caretakers to plant a grape vine to provide some shade over the front. Will the refugees still be at Moria when we next visit? I sincerely hope not but given the current political climate there is no end in sight. Will I ever be able to claim ownership of the shack given the complexity of the bureaucracy involved? Many have given up and relinquished any claim to ownership as it is so complicated. I have hoped that this place can be one of charity and learning but the management of this has become the greatest obstacle to its realisation. I have imagined this space to function as a place of public pedagogy, an artist retreat, a space for workshops and engagement.

I have heard on many occasions, second-generation Australians referring to their hyphenated existence. "I am not a hyphen, I am a 100-metre dash" says Luka Lesson, an Australian poet of Greek heritage. But walking is by no means a dash, its intentional slow but steady pace immerses one in time and space, offering a glimpse at what it may mean to be connected to country.

(Luka Lesson, excerpt from Amber Lights http://www.lukalesson.com.au/blog/amber-lights)

\section{Postscript}

On the evening of 14 September, 2020, the camp at Moria was set on fire and 13,000 refugees poured onto the roads and countryside of Lesbos. It is with a heavy heart I finish this writing. 


\section{References}

Sandlin, JA, Schultz, B \& Burdick, J (eds.), Handbook of Public Pedagogy: Education and Learning Beyond Schooling, Routledge, New York.

Massumi, B. 2017, The Principle of Unrest Activist Philosophy in the Expanded Field, Open Humanities Press

Powell, K. 2019. Walking as Precarious Public Pedagogy, Journal of Public Pedagogies, Number 4. ISSN 2207-4422 p199.

Springgay, S and Truman, S. E. 2018, Walking Methodologies in a More-than-Human World: WalkingLab, Routledge, New York 